\title{
MAKNA SIMBOL SENYUMAN DALAM CERPEN PEREMPUAN SUNYI DAN SAUDARANYA KARYA YUS R. ISMAIL
}

\author{
Yuliadi M.R. \\ Kantor Bahasa Provinsi Lampung \\ Pos-el: yyuliadi.muh.rahim@gmail.com
}

\begin{abstract}
A bstrak
Penelitian ini dilakukan untuk mengungkap makna simbol senyuman dalam cerpen Perempuan Sunyi dan Saudaranya karya Yus R. I smail. A spek simbol senyuman itu diungkap mel alui peristiwa dan dialog tokoh dalam cerpen. Teori yang digunakan dalam penelitian ini adalah teori semiotika. Metode yang digunakan dalam penelitian ini adalah metode deskriptif kualitatif dengan teknik pengumpulan data studi pustaka. Hasil yang diperoleh dalam penelitian ini adalah cerpen Perempuan Sunyi dan Saudaranya berisi simbol universal, simbol kultural, dan simbol individual.
\end{abstract}

Kata kunci: Makna simbol, cerpen Perempuan Sunyi dan Saudaranya, semiotika

\begin{abstract}
This research is conducted to reveal the symbol smile meaning in Perempuan Sunyi dan Saudaranya short story by Y us R. I smail. This symbol aspect would berevealed through thedepiction of incident in thestory and dialogue. The theory used in this study was The Semiotic theory. The method used in this research was qualitativedescriptive method whilst data collection used literary technique. Theresults obtained in this study was Perempuan Sunyi dan Saudaraanya short story form universal symbols, cultural symbols and individual symbols.
\end{abstract}

Keyw ords: Symbol meaning, Perempuan Sunyi dan Saudaranya short story, semiotics

\section{PEN DAHULUAN}

Dalam masyarakat terdapat simbol-simbol yang berkaitan dengan kehidupan. Agar tidak lengah dalam kehidupan tersebut, kita dituntun untuk dapat membaca dan memahami hal tersebutsimbol itu. A ktualisasi simbol dapat diamati dalam karya sastra. Karya sastra me rupakan refleksi pemikiran dan perasaan pengarang melalui bahasa. Setiap karya sastra menggunakan simbol yang memiliki makna tersendiri. Simbol-simbol itu diungkapkan dengan bahasa yang khas. Simbol-simbol itulah yang perlu kita pahami atau maknai (Pierce dalam Santoso, 1993:11-12).

Dalam cerpen Perempuan Sunyi dan Saudaranya karya Yus R. Ismail, yang dimuat M edia Indonesia, 10 September 2017, terdapat simbol-simbol. Simbol tersebut dapat diinter- pretasi dan dimaknai. Sesuatu dalam teks sastra, termasuk cerpen, mungkin dilihat sebagai simbol, mungkin juga tidak, itu bergantung pada interpretasi pembaca (Luxemburg, 1989:69). Pembaca berhak menafsirkan simbolsimbol tersebut secara arbitrer. Artinya pembaca dapat melihat sesuatu dalam teks sastra tersebut sebagai simbol, juga dapat tidak melihat sesuatu itu sebagai simbol.

Penelitian tentang simbol pernah dilakukan. Di antaranya oleh Rosyada (2014) dengan judul Simbol "Gila" dalam Cerpen Catatan H arian Orang Gila Karya Lu X un mengungkapkan perilaku seorang "gila" yang melanggar tradisi masyarakat Cina. Dalam penelitian itu diungkap makna simbol gila dengan analisis tokoh. Rifai (2011) dalam penelitiannjya berjudul Simbol dan Makna Novel Candhikala Kapuranta 
Karya Sugiarta Sriwibawa, mengungkapkan simbol dan makna terdapat dalam novel Candhikala Kapuranta berdasarkan teori struktural A. Teeuw berupa kode bahasa, kode sastra, dan kode budaya. Aini (2013) dalam penelitiannya berjudul A nalisis Semiotik terhadap N ovel Laskar Pelangi karya A ndrea H irata Sebagai Alternatif Bahan Pengajaran Sastra di SMA, mengungkapkan tanda dalam novel dengan pendekatan semiotik Charles Sanders Pierce, berupa ikon, indeks, dan simbol tentang makna kostum, nama, kekayaan, dan kemiskinan.

Dalam penelitian ini penulisfokuskan pada analisis makna simbol senyuman dalam cerpen Perempuan Sunyi dan Saudaranya dengan pendekatan objektif menggunakan teori semi otika. Pendekatan objektif (Teeuw, 1984:134), yaitu pendekatan yang memfokuskan pada karya (teks). A brams dalam Endraswara (2008:9) menjelaskan bahwa pendekatan objektif berfokus pada karya sastra itu sendiri disebut strukturalisme. Teori semi otika dipakai untuk mengungkap makna simbol senyuman dalam cerpen.

Penelitian ini penting dilakukan terhadap cerpen Perempuan Sunyi dan Saudaranya karya Yus R. Ismail karena, pertama, di dalam cerpen tersebut simbol-simbol. Simbol tersebutmemiliki makna tertentu. Kedua, masalah pengungkapan makna simbol senyuman dalam cerpen Perempuan Sunyi dan Saudaranya karya Yus R. Ismail dengan teori semiotik belum pernah dilakukan. Ketiga, makna simbol senyuman dalam cerpen Perempuan Sunyi dan Saudaranya karya Yus R. Ismail dapat diambil pengetahuan dan pengalaman dalam menjalani kehidupan ini.

Sehubungan dengan itu, rumusan masalah dalam penelitian ini adalah "Bagaimanakah makna simbol senyuman dalam cerpen Perempuan Sunyi dan Saudaranya karya Yus R. Ismail dengan teori semiotika?". Sebelum menjawab masalah itu ditentukan tujuan penelitian, yaitu untuk mengungkap makna simbol senyuman dalam cerpen Perempuan Sunyi dan Saudaranya karya Yus R. Ismail dengan teori semiotika.
Teori semiotika digunakan untuk mengungkap makna simbol melalui gambaran dan dialog tokoh dalam teks cerpen.

\section{TEORI DAN METODE}

Teori semi otika tersebut dipakai dal am berbagai bidang tidak lepas dari gagasan yang bersifat menyeluruh (mengaitkan unsur tanda secara logis), serta deskripsi struktural dari semua sistem penandaan (Sobur, 2009:97). Selain itu, semiotika Peircean bersifat pragmatik, yakni semiotika yang mempelajari hubungan di antara tanda-tanda dengan interpreternya atau para pemakainya (Budiman, 2011:4).

Peirce menjelaskan tiga unsur dalam tanda, yaitu representamen, objek, dan interpretan. Ketiga unsur tersebut saling berhubungan, hubungan pengiriman tanda dan penerimaan tanda yang disebut proses semiosis (Zaimar, 2008:4). Pierce dalam Lyons (1984:100-109), mengklasifikasikan tanda-tanda menjadi tiga macam. Pertama, simbol adalah tanda yang akan kehilangan karakter jika tidak ada penafsirnya. Kedua, ikon adalah tanda yang memiliki karakter dan menjadikan itu berarti, meskipun objek tidak memiliki ekstensi. Ketiga, indeks adalah tanda-tanda yang menjadikan karakter menjadi tanda jika objeknya dihapus, tetapi tidak akan kehilangan karakter tanpa penafsiran dengan kata lain yang memiliki makna tertentu.

Endraswara (2011:65) menyatakan bahwa simbol adalah tanda yang memiliki hubungan makna dengan yang ditandakan bersifat arbitrer, sesuai dengan konvensi suatu lingkungan sosial tertentu sedangkan pengertian simbol menurut Luxemburg (1989:67) adalah lambang, sesuatu yang berdasarkan perjanjian atau konvensi mengacu pada gagasan atau pengertian tertentu. Simbol diabstraksikan ke dalam konteks sastra seperti pengaturan, karakter, tindakan, benda, nama, atau apapun di dunia yang mengacu pada makna lain. Simbol ataupun lambang adalah suatu konsep yang berada di dunia ide atau pikiran kita 
(Chaer, 2002:38). Barnet dan Burto (1992:471) mendefinisikan simbol sebagai gambar sehingga sarat dengan makna bahwa tidak hanya sastra. Hal ini penting bagi pembaca untuk memahami makna yang tercermin oleh simbol-simbol.

Simbol memiliki arti yang kompleks, tidak hanya mengandung arti dalam sastra, tetapi juga makna tambahan di luar sastra. Terkadang arti harfiah dari simbol tidak masuk akal, sehingga makna simbolitas muncul dan membatalkan makna sastra. Simbol mungkin memiliki lebih dari satu arti. Dalam sastra, simbol bisa berupa bentuk kata, gambar, objek, pengaturan, peristiwa, dan karakter yang sering digunakan untuk menunjukan dan memperkuat makna, dan untuk membantu mengatur serta menyatukan keseluruhan kata.

Pickering dan Hoeper (1981 :70), menyatakan bahwa identifikasi dan pemahaman simbol sastra memerlukan banyak membaca serta dibutuhkan kesadaran dan kecerdasan dalam mendeteksi unsur-unsur tertentu dalam simbol yang bisa merumuskan suatu makna, hal itu tidak terbatas hanya dengan apa yang tertulis dalam sastra. Rahmanto (Sumarto, 1984:133) membedakan tiga simbol bahasa: pertama, simbol universal berkaitan dengan arketipus, misalnya tidur sebagai lambang kematian; kedua, simbol kultural yang melatarbelakangi suatu kebudayaan tertentu; dan ketiga, simbol individual dipakai ke dalam studi bahasa masyarakat dan lingkungan.

Mead (Supratno, 2010:23) menjelaskan bahwa makna simbol bukan terletak pada proses mental, tetapi terletak pada proses interaksi sosial. Dalam kehidupan sehari-hari manusia tidak hanya berinteraksi dengan orang lain, tetapi secara simbolik ia juga berinteraksi dengan dirinya sendiri. Supratno (2010:23) mengungkapkan bahwa interaksi simbolik dilakukan dengan menggunakan bahasa sebagai satu-satunya simbol yang terpenting dan melalui isyarat. Simbol bukan merupakan fakta-fakta yang sudah jadi, tetapi simbol berada dalam proses yang kontinu. Simbol, khususnya bahasa, tidak hanya memungkinkan manusia dapat berkomunikasi dengan sesamanya, tetapi simbol juga merupakan alat berpikir, sebagai alat berkomunikasi dengan dirinya sendiri.

Dari pendapat di atas dapat dikatakan bahwa memaknai simbol diperlukan kesadaran dan kecerdasan dalam mendeteksi unsurunsur tertentu di dalamnya. Sehingga dapat dirumuskan suatu makna. Untuk mendapat makna tersebut dapat dilihat dengan membagi tiga simbol bahasa, yaitu simbol universal, simbol kulutral, dan simbol individual. Dengan demikian, pemaknaan simbol dapat dilakukan tepat.

Simbol dalam cerpen Perempuan Sunyi dan Saudaranya karya Yus R. Ismail dianalisis dengan teori semiotika berupa simbol-simbol, yaitu simbol universal, simbol kultural, dan simbol individual. Simbol-simbol itu memiliki makna tertentu. Makna itu akan memberikan pengetahuan dan pengalaman yang berguna bagi kehidupan.

Data penelitian ini adalah data primer, yaitu cerpen Perempuan Sunyi dan Saudaranya karya Yus R. Ismail, yang dimuat M edia Indonesia, 10 September 2017. Penelitian ini merupakan kajian deskriptif dengan metode kualitatif. Metode kualitatif (Moleong, 2005:6) digunakan untuk mengumpulkan data deksriptif berupa teks cerpen. Dalam penelitian ini data yang dikumpulkan adalah data berupa perilaku gambaran dan dialog tokoh dalam teks cerita yang mengandung simbol senyuman. Data dianalisis dengan metode pemahaman dan penafsiran dalam pandangan semiotika.

Informasi didapat dari analisis hasil cerita pada teks cerpen yang selanjutnya sebagai data. Data yang diperoleh kemudian dianalisis dengan dilakukannya interpretasi dan dilanjutkan pendeskripsian. Teknik dalam penelitian, yaitu teknik menganal isis data berupa, pertama, mengadakan studi kepustakaan dilakukan untuk mendapatkan data yang menyangkut 
makna simbol. Kedua, menginventarisasikan data simbol senyuman dari teks cerpen melalui penggambaran dan dialog tokoh. Ketiga, mengindentifikasi data yang diperoleh yang menyangkut aspek semiotika berupa makna simbol senyuman. Keempat, merumuskan simpulan penelitian tersebut.

\section{Sinopsis Cerita}

Perempuan Sunyi, orang-orang menyebutnya. Tokoh saya tidak dapat bersuara apalagi berbicara. Sering ada yang bertamu ke rumah nenek, setelah lama berbincang dengan nenek atau kakek, baru menyadari kehadiran saya di kursi pojok sedang membaca buku. Anelis be gitu nenek memperkenalkan saya kepada tamu. Lalu, tamu akan mengomentari diri saya dengan memuji cantik dan berambut indah.

Nenek akan tersenyum mendengarnya. Padahal jika nenek tidak ada, tamu akan berkomentar berbeda. Mereka akan mengatakan kasihan sekali, cantik-cantik, tetapi bisu, tuli, dan lumpuh. A pa pun komentar mereka, saya akan tetap tersenyum. Hanya senyumlah yang dapat saya ungkapkan.

Kata nenek, saya sudah bisu, tuli, dan lumpuh sejak lahir. Meski begitu, ketika saya lahir ada suara tangis bayi yang keras. Suara tangis bayi yang membuat pendengarnya bersyukur. Tapi suara tangis itu bukan keluar dari mulut saya. Suara tangis itu kepunyaan saudara kembar saya, namanya Inalis.

Nenek selalu bilang, di antara kami berdua yang lebih mirip ibu adalah saya. Ibu adalah perempuan yang cantik dengan rambut indah bergelombang, mata cerlang bercahaya, dan senyum seperti bunga yang selalu mekar. Ibu pun perempuan sunyi; bisu, tuli, dan lumpuh.

Kata orang, saya dan Inalis seperti pinang dibelah dua. Hanya yang membedakannya, Inal is lebih besar dan tinggi. Karena sejak kecil Inalis biasa bergerak, menari, menyanyi, dan bermain berlari-larian. Sementara saya hanya menemaninya dari pinggir halaman, tersenyum, bertepuk tangan, dan ngesot untuk mengejarnya.
Inalis sangat menyayangi saya, seperti juga saya sangat menyayanginya. Inalis selalu membantu saya. Saya dipangkunya untuk dipindahkan dari lantai ke kursi atau tempat tidur. Saya digendongnya ketika ingin melihat pawai kendaraan hias saat perayaan hari kemerdekaan. Saya diberinya makanan dan mainan apa pun yang dipunyainya.

Hanya saja Inalis tidak pernah bisa menguasai bibirnya. Bila sudah marah, bicaranya akan panjang, mengomel mengatai apa pun yang tidak berhubungan dengan yang membuatnya marah. Akibat tidak mampu menguasai mulutnya, Inalis menjadi tersiksa. Dirinya menjadi tidak terkendali dan terjerumus oleh mulutnya. Di akhir hayatnya, Inalis berkeinginan menjadi A nelis yang penuh senyumdan diam membisu.

\section{HASIL DAN PEMBAHASAN}

Dari pendekatan yang memfokuskan pada teks cerpen Perempuan Sunyi dan Saudaranya dengan diungkap melalui penggambaran dan dialog tokoh didapat simbol-simbol. Lalu, simbol dalam teks cerpen Perempuan Sunyi dan Saudaranya karya Yus R. Ismail dianalisis dengan teori semiotika didapat makna simbol universal, yaitu, pertama, simbol yang berkaitan dengan arketipus; kedua, makna simbol kultural, yaitu simbol yang melatarbelakangi suatu kebudayaan tertentu; dan ketiga, makna simbol individual, yaitu simbol yang dipakai ke dalam studi bahasa masyarakat dan lingkungan. Makna simbol senyuman tersebut akan diurai lebih rinci dalam pembahasan sebagai berikut.

\section{A. Simbol Universal Senyuman}

Dalam pendekatan cerpen Perempuan Sunyi dan Saudaranya terdapat simbol universal. Simbol universal ini terdapat pada makna senyuman. Senyuman tokoh si Perempuan Sunyi memberikan makna santun dan akrab, terlihat dalam kutipan berikut. 
"O h, itu A nelis cucu Ibu itu, ya?" tanya tamu sambil tersenyum kepada saya. $\mathrm{N}$ enek selalu mengangguk menjawab pertanyaan seperti itu. Sang tamu kemudian menghampiri saya. "Oh, cantik sekali. Rambutnya begitu indah, matanya begitu cerlang."

Kutipan di atas menjelaskan bahwa senyuman yang ditujukan kepada Perempuan Sunyi merupakan bentuk ungkapan sapaan. Sapaan yang dapat diartikan sebagai bentuk santun, akrab, atau basa-basi. Senyuman yang diberikan tamu kepada Perempuan Sunyi dikatakan simbol pola umum, suatu bentuk pengawal dalam pembicaraan, sebelum dilanjutkan pada pembicaraan tertentu.

Makna simbol universal terlihatjugadalam pembicaraan nenek dengan tamu. Dalam dialog itu terdapat makna ketidaktegaan. Makna itu akan muncul dalam peristiwa sedih, haru, atau duka, seperti dalam kutipan berikut.

$N$ enek selalu tersenyum mendengarnya. M ungkin karena tahu, bila tidak ada nenek, komentar tamu atau orang lain yang melihat saya itu sedikit ada penyimpangan. M ereka akan mengatakan seperti ini: "Kasihan sekali, cantik-cantik kok bisu, tuli, dan lumpuh."

Simbol senyuman ini membentuk pola dasar yang menjadikan makna tertentu. Suatu simbol yang lebih luas dan umum, menunjuk pada makna yang baru. Makna yang baru itu adalah suatu bentuk kesedihan atau ketidaktegaan. Perempuan Sunyi yang cantik dan berambut indah serta mata yang cermerlang tetapi tidak dapat berbicara, hanya senyuman yang dapat disampaikannya. Hal inilah yang dikatakan simbol universal yang bermakna baru.

Ya, karena saya tidak bisa bicara. Sudah lama saya berlatih, setiap ingin bicara atau berteriak saya mengalihkannya dengan tersenyum. Karena suara yang keluar dari mulut saya hanya melenguh. $D$ an saya tidak menyukai suara lenguhan.
Dalam kutipan di atas menjelaskan sesuatu yang ironis. Si aku selalu tersenyum kendati orang-orang membicarakannya. Si aku pun menyadari kelemahannya. Sudah Iama dia berlatih untuk bicara, tetapi suara lenguh yang keluar. Inilah alasan mengapa si aku akan tersenyum ketika orang lain mengomentari dirinya. Si aku memang menyadari bahwa sejak lahir dirinya telah mengalami kekurangan. $\mathrm{Hal}$ itu terlihat dalam kutipan berikut.

$\mathrm{N}$ enek selalu bilang, di antara kami berdua yang lebih mirip ibu adalah saya. I bu adalah perempuan yang cantik dengan rambut indah bergelombang, mata cerlang bercahaya, dan senyum seperti bunga yang selalu mekar. I bu pun perempuan sunyi; bisu, tuli, dan lumpuh.

Nenek menjelaskan bahwa fisik si aku sangat mirip dengan ibu. Ibu adalah perempuan yang cantik dengan rambut yang indah. Mata penuh cahaya dan senyumnya seperti bunga yang selalu mekar. Akan tetapi, dia sama seperti si aku. Dia perempuan sunyi, bisu, tuli,dan lumpuh. Juga semyumanlah sebagai alat untuk menjawab dan menanggapi omongan orang lain.

Simbol universal dalam cerpen Perempuan Sunyi dan Saudaranya memberi makna bahwa kata senyuman merujuk pada kesedihan atau ketidaktegaan, bentuk dari ungkapan yang tidak terucapkan. $\mathrm{Hal}$ itu terlihat dalam perilaku dan peristiwa yang dialami tokoh dalam cerpen. Perilaku tokoh itu dapat diamati dalam ucapan atau perkataan yang diungkapkannya. Begitu pula peristiwa yang terjadi berpengaruh terhadap sikap dan ucapan tokoh.

Untuk itulah, hal yang dialami si aku dalam cerpen, sesuatu yang tidak terucapkan. Sesuatu yang tidak terucapkan itu membentuk simbol baru, yaitu senyuman. Untuk itulah, senyuman dapat dimaknai bentuk ungkapan dari sesuatu yang tidak tersampaikan, aktualisasi dari kepedulian, kesedihan, atau ketidaktegaan. 


\section{B. Simbol Kultural Senyuman}

Dalam cerpen Perempuan Sunyi dan Saudaranya didapat simbol kultural, yaitu simbol yang berkaitan dengan kultur suatu orang atau kelompok masyarakat tertentu. Senyuman tokoh si Perempuan Sunyi yang bermakna memberikan makna keakraban, terlihat dalam kutipan berikut.

A papun komentar mereka, saya akan tersenyum. Y a, karena saya tidak bisa bicara. Sudah lama saya berlatih, setiap ingin bicara atau berteriak saya mengalihkannya dengan tersenyum. Karena suara yang keluar dari mulut saya hanya melenguh. Dan saya tidak menyukai suara lenguhan.

Kutipan di atas menjelaskan bahwa simbol senyuman yang digambarkan tokoh saya merupakan bentuk simbol kultur. Simbol yang merupakan kultur dari tokoh saya, lingkungan tokoh saya, dan masyarakat tokoh saya, yang hidup saling menghargai dan saling menyantuni. Ketika dalam sebuah pertemuan terjadi saling bertatap muka, seseorang akan saling sapa. Jika tidak saling kenal, mereka akan berusaha tersenyum sebagai bentuk sapaan.

Simbol kultural juga terlihat dalam peristiwa yang dialami oleh tokoh ibu si aku. Dia menangis sepulang dari bermain. Dia hanya bisa melenguh-lenguh dengan air mata yang membasahi pipi, seperti terlihat dalam kutipan berikut.

Suatu hari sepulang bermain di teras belakang rumah, ibu menangis. M el enguhlenguh, lalu diam dengan air mata mengalir membasahi pipinya yang ranum. Tangis yang tidak biasa. Karena berharihari kemudian, berminggu-minggu kemudian, tangis itu tidak berhenti.

Kutipan di atas mengungkapkan simbol yang dialami oleh tokoh ibu. Ibu menangis sepulang dari bermain di belakang rumah. Dia hanya bisa menangis hingga berhari-hari. Bahkan berminggu-minggu tidak juga berhenti. $\mathrm{Hal}$ ini membuat nenek dan kakek bingung.
A khirnya, kebingungan nenek dan kakek terjawab ketika ibu beberapa minggu tidak juga datang bulan. Ibu selalu menangis ketika ditanya siapa yang menghamilinya. Sampai akhir hayat ibu nenek dan kakek tidak tahu siapa sebenarnya ayah Inalis dan saya.

Simbol kultural yang diungkapkan dari peristiwa ini adalah suatu kepedihan. Kepedihan itu tidak dapat rasakan lagi hingga senyumanlah sebagai jawabannya. Selain itu, senyuman menjadi jawaban yang paling kuat untuk menjadi jawaban dari semua tanya yang tidak berjawab.

Simbol kultural pun terlihat dalam sikap ibu yang berusaha memaafkan dan melupakan orang-orang yang telah menyakitinya. Dia berusaha menyimpan kesediahan yang dialaminya. Juga menghibur diri dengan menyulam, seperti terlihat dalam kutipan berikut.

Nenek dan kakek tentu saja bingung. Tapi kemudian ibu melupakan tangisnya. Ibu sibuk lagi dengan keterampilan menyulamnya, keterampilan yang diajarkan nenek sejak kecil. A pa pun disulamnya. Taplak meja, sarung bantal, bajunya, hiasan dinding, dan apa pun. Sebagian hasil sulaman ibu dibagikan kepada saudara-saudara yang datang dan tetangga.

Kutipan di atas menjelaskan bahwa tokoh ibu memcoba melupakan peristiwa tragis yang menimpanya. Peristiwa yang membuat dirinya menangis. Ibu menyibukkan diri dengan menyulam. Keterampilan yang didapat dari nenek. H asil sulaman berupa taplak meja, sarung bantal, baju, hiasan dinding, dan apa pun dibagikannya kepada saudara yang datang. Juga dibagikan kepada tetangga. $\mathrm{Hal}$ itu merupakan bentuk sikap maaf yang ingin ditunjukkan ibu. $\mathrm{Hal}$ ini juga merupakan bentuk keikhlasan untuk melepaskan kepedihan.

"Coba, kamu tahu apa arti senyum Pe rempuan Sunyi itu kali ini?" tanya seseorang kepada temannya saat melihat saya sedang menyulam di teras rumah. Saat itu senja turun dengan matahari jingga kekuningan. 
"M ungkin dia bangga bisa membuat sulaman," jawab temannya.

"Bukan. D ia pasti berbahagia begitu menyadari bahwa dirinya tidak bisa bicara."

"H aha... masak karena bisu jadi bahagia?"

"Iya, karena dia tahu, banyak berkatakata sering kali menutup orang untuk tersenyum."

M endengar percakapan seperti itu senyum di bibir saya semakin merekah.

Senyuman si Perempuan Sunyi memang penuh misteri. Saat seseroang berjal an di depan rumahnya, Ialu temannya bertanya, apa arti senyumsi Perempuan Sunyi itu? Tidak ada satu jawaban yang pasti. Mulai dari arti kebanggaan, kebahagiaan, dan Iainnya. Ketika jawaban itu didengar si Perempuan Sunyi, dia tersenyum semakin merekah.

Perempuan Sunyi menyadari bahwa senyum adalah luapan perasaannya. Luapan pe rasaan itu membentuk suatu kebiasaan. Lalu, kebiasaan itu akan membentuk kultur. Sesuatu yang menjadi kebutuhan dan kebiasaan. Sehingga senyum menjadi simbol dari sebuah kultur.

Simbol kultur dalam cerpen Perempuan Sunyi dan Saudaranya didapat makna bahwa kata senyuman membentuk suatu makna yang merujuk pada karakter diri atau kelompok. Karakter diri atau kelompok tersebut membudaya dalam kehidupan. Simbol yang membudaya itu adalah saling bertegur sapa. Ketika tegur sapa itu tidak terucapkan, senyuman merupakan salah satu bentuk ekpresi diri bentuk pengungkapannya. Untuk itulah, senyuman dapat dimaknai bentuk ungkapan saling sapa antardiri atau kelompok yang diimplementasikan dalam pergaulan pada masyarakat. Akhirnya, hal itu menjadi simbol kultural masyarakat.

\section{Simbol Individual Senyuman}

Dalam cerpen Perempuan Sunyi dan Saudaranya didapat simbol individual, yaitu simbol yang berkaitan atau berhubungan dengan manusia secara pribadi atau bersifat perseorangan. Senyuman tokoh si Perempuan Sunyi yang bermakna memberikan makna kepribadian, terlihat dalam kutipan berikut.

A papun komentar mereka, saya akan tersenyum. Ya, karena saya tidak bisa bicara. Sudah lama saya berlatih, setiap ingin bicara atau berteriak saya mengalihkannya dengan tersenyum. Karena suara yang keluar dari mulut saya hanya melenguh. $D$ an saya tidak menyukai suara lenguhan.

Kutipan di atas menjelaskan bahwa makna senyum yang digambarkan tokoh si Perempuan Sunyi adalah suatu simbol individual. Simbol individual yang ditunjukkan, yaitu simbol si Perempuan Sunyi yang tidak dapat berkata-kata. Dirinya tidak dapat berkata-kata hanya mengeluarkan suara lenguhan saja. Untuk itulah, dengan senyum si Perempuan Sunyi menjawab pertanyaan dan perkataan lawan bicaranya.

Kata nenek, saya sudah bisu, tuli, dan Iumpuh sejak lahir. M eski begitu, ketika saya lahir ada suara tangis bayi yang keras. Suara tangis bayi yang membuat pendengarnya bersyukur. Tapi suara tangis itu bukan keluar dari mulut saya. Suara tangis itu kepunyaan saudara kembar saya, namanya Inalis.

Ketidakmampuan bicara si Perempuan Sunyi memang sejak lahir. Dia memiliki saudara kembar. Kembarannya mampu berbicara. Tangisnya sangat keras ketika lahir. A kan tetapi, tokoh si Perempuan Sunyi sejak Iahir dirinya bisu dan tuli. Tidaklah berlebihan bahwa alat komunikasi yang dapat dikatakannya hanya dengan senyum. Senyum tersebut merupakan simbol pribadi dari si Perempuan Sunyi. Senyumnya telah manjadi identitas baginya. Setiap orang akan menandai dirinya sebagai perempuan yang dipenuhi senyuman.

Berbanding terbalik dengan kembaran si Perempuan Sunyi. Inalis lebih besar dan tinggi. Karena kebiasaan bergerak, menari, menyanyi, 
dan bermain Iari-Iarian, Inalis menjadi berkembang sempurna. Jauh berbeda dengan si Perempuan Sunyi yang hanya diam di pinggir halaman, tersenyum, bertepuk tangan, dan ngesot. Selain itu, kembarannya, Inalis, justru tidak dapat menguasai bibirnya. Dirinya akan selalu berbicara. Tidak hanya itu dirinya akan selalu mengomel mengatai apa pun yang tidak berhubungan dengan yang membuat dirinya akan marah. Hal itu terlihat dalam kutipan berikut.

Kata orang, saya dan Inalis seperti pinang dibelah dua. $\mathrm{H}$ anya yang membedakannya, Inalis lebih besar dan tinggi. Karena sejak kecil Inalis biasa bergerak, menari, menyanyi, dan bermain berlarilarian. Sementara saya hanya menemaninya dari pinggir halaman, tersenyum, bertepuk tangan, dan ngesot untuk mengejarnya.

H anya saja Inalis tidak pernah bisa menguasai bibirnya. Bila sudah marah, bicaranya akan panjang, mengomel me ngatai apa pun yang tidak berhubungan dengan dengan akan membuatnya marah.

Kutipan di atas menjelaskan Inalis tidak dapat menguasai dirinya. Dirinya akan terus berbicara. Berbicara panjang. Juga akan mengomel dan mengatai tentang apa pun yang tidak ada kaitannya. Seakan-akan bibirnya tidak dapat dikendalikan. Hal ini menjadikan Inal is sedih dan menangis.

Sejak itu saya tidak ingin bisa bicara seperti Inalis bicara. Keinginan yang sejak saya ingat dan sadar bahwa saya tidak bisa bicara seperti itu, berhenti begitu saja. Seperti sinar matahari yang tertutup awan dan hujan. Saya Ialu lebih memercayai tersenyum sebagai kata-kata. I tulah awalnya mengapa saya dikenal sebagai Perempuan Sunyi yang selalu tersenyum.

Si Perempuan Sunyi menyadari dirinya berbeda dengan kembarannya, Inalis. Dirinya tidak dapat berbicara, seperti sinar matahari yang tertutup awan dan hujan, sehingga si Perempuan Sunyi hanya memercayai senyum sebagai kata-kata. Sejak itulah si Perempuan Sunyi dijuluki perempuan yang selalu tersenyum.

Sesuatu yang ironi dialami tokoh si aku. Dia tidak bisa bicara, tuli, dan ramah sedangkan Inalis, kembarannya, dia juga baik. Akan tetapi, bila sudah bertengkar, dia akan bersikap keras, pemarah, dan kejam. Hal itu terlihat dalam kutipan berikut.

Setelah kami dewasa, kata-kata seperti kutukan bagi Inalis. Dia sangat baik kepada siapa pun. Tapi begitu sudah berselisih, mulutnya seperti senapan yang tidak akan berhenti sebelum ada peristiwa besar. Sekali waktu, saat Inalis SM P, teman akrabnya sendiri dikatakan pelit, bodoh, tidak tahu diri, kurang ajar, sengsara, buruk rupa, pecundang, dan entah apa lagi; hanya karena tidak memberinya pinjaman buku. Tentu saja temannya itu marah. Dia memutuskan hubungan pertemanannya.

Sikap si aku dan Inalis sangat berbeda. Mereka sangat baik,tetapi perbedaan dua saudara kembar ini sangat jauh. Si aku dapat mengendalikan diri sedangkan Inalis sangat temperamen. Si aku akan membalas dengan senyuman kepada setiap orang yang menggunjinginya. Inalis mudah tersinggung dan mudah marah.

Sikap si aku yang mudah senyum menjadi simbol individu baginya sedangkan sikap keras dan temperamen untuk Inalis. Hal ini menjadi simbol individu yang sangat kuat. Simbol individu ini menjadi identitas diri yang terlihat dalam sikap dan perilaku. Simbol ini akan melekat dalam diri seseorang dan menjadi ciri bagi dirinya.

Senyuman si Perempuan Sunyi menjadi simbol dirinya. Identitas diri sebagai indiviudal. Senyum yang bermakna tanda Perempuan Sunyi. Perempuan yang menerima apa adanya tentang dirinya. Tidak peduli bagaimana dan 
apakah seseorang membicarakan dirinya baik atau tidak, dirinya akan tetap tersenyum. Senyuman menjadi alat untuk menungkapkan dan mengekpresikan kebahagian, kesedihan, dan ketidakterimaan juga sebagai bentuk pe nolakan. Dengan senyuman si aku merasakan bahwa dirinya telah menjadi sempurna. Melepaskan kebisuan, ketulian, dan ketidakmampuan diri.

Tidaklah berlebihan bahwa sebagian orang menyatakan mulutmu adalah harimaumu. A kibat perkataan yang tidak terkendali, seseorang akan terjerumus dalam celaka. Makna senyuman bila dikontraskan dengan celoteh, tentu akan sangat jelas akibatnya. Senyuman yang diwakili oleh tokoh si Perempuan Sunyi membuat dirinya merasa kehidupan begitu indah, sebaliknya celotehan yang diwakili Inalis membuat dirinya akan merasa tersiksa oleh mulut saudaranya. $\mathrm{Hal}$ itu terlihat dalam kutipan berikut.

Sekali waktu Inalis menangis. Ujung bibirnya robek berdarah. A walnya hanya karena ada orang yang lewat tidak bilang permisi. Mulut Inalis Ialu menjadi senjata lagi mengeluarkan perbendaharaan kata yang begitu tidak terbayangkan banyaknya. Setiap orang itu lewat, mulut Inalis menembaknya dengan jutaan kata-kata. Orang itu awalnya bingung. Tapi begitu tahu kata-kata sumpah serapah dan ejekan itu ditujukan kepadanya, orang itu memukul Inalis.

Inalis memeluk saya. "A n, tahukah engkau, sejak dulu, sejak kita kecil, aku ingin sepertimu," katanya sambil menangis. "A ku ingin bisu sepertimu."

Saya tentu saja tersenyum sambil membelai rambutnya.

Kutipan di atas menjelaskan Inalis me nangis. Ujung bibirnya berdarah karena sobek. Dirinya dipukul oleh seseorang karena celoteh Inalis yang penuh sumpah serapah dan ejekan. Mulutnya telah menyiksanya. Dirinya tidak dapat mengendalikannya. Inalis memeluk is Perempuan Sunyi berkata dirinya ingin seperti engkau, si Perempuan Sunyi, "Aku ingin bisu sepertimu". Si Perempuan Sunyi hanya tersenyum. Senyum telah menjadi sesuatu yang sangat berharga. Senyum dapat menjadi senjata bagi dirinya, juga menjadi identitas yang kuat dalam dirinya.

Inalis merupakan tokoh yang tidak dapat mengendalikan diri. Sikap dan perilaku yang dimilikinnya membentuk kepribadian yang lemah, cengeng, dan emosif. Hal terlihat dalam kutipan berikut.

Sekali waktu keinginan Inalis untuk bisu itu terkabul. Dia tidak bisa berteriak, menembak orang dengan kata-katanya yang tajam, bahkan melenguh pun tidak bisa. Saya memeluknya. "Bicaralah, In, bicaralah seperti biasa," bisik saya. Tapi Inalis membisu.

D arah segar membasahi tangan saya saat tersentuh belati yang menancap di dada Inalis.

Kutipan di atas menjelaskan tokoh Inalis yang keras dan tidak terkendali. Dia menjadi tersiksa dengan kepribadian yang dimilikinya. Suatu waktu Inal is berkeinginan untuk menjadi diri si aku, yang bisu dan selalu tersenyum. Ke ingian itu pun terkabul. Dia tidak dapat berteriak dan berkata dengan kata-kata tajam. Bahkan untuk melenguh pun dia tidak bisa. Inalis membisu. Dia putus asa dengan keadaan dirinya. Mulutnya telah menjadikan dirinya orang yang keras, kejam, dan temperamen. Untuk itulah, untuk mewujudkan diri menjadi seorang yang penuh dengan senyum dan tanpa banyak kata-kata, belati harus tertancap di dada Inalis. A khirnya, Inalis menjadi diri yang diam dan tidak berkata-kata. Hanya dengan cara itulah Inalis dapat menjadi simbol individual yang penuh senyum.

Simbol individual dalam cerpen Perempuan Sunyi dan Saudaranya memberi makna bahwa kata senyuman merujuk pada ciri seseorang atau individu. Simbol diri tersebut membentuk konsep tentang pandangan orang terhadap diri dalam kehidupan. Simbol indivual itu adalah 
diam dan senyum. Ketika menghadapi peristiwa atau situasi tertentu, diri akan mengaktualisasikan keadaan itu dengan senyuman. Senyuman merupakan bentuk ekspresi dari suka, setuju, melawan, menghindar, atau mengkritik. Untuk itulah, senyuman dapat dimaknai bentuk ungkapan diri yang 'penuh dengan makna sehingga menjadi identiatas diri. Identitas itu menjadi tanda bagi dirinya. A khirnya, hal itu menjadi simbol individual.

\section{Makna Simbol Senyuman}

Simbol yang menjadi penanda dalam cerpen Perempuan Sunyi dan Saudaranya adalah perilaku yang ditunjukkan tokoh. Perilaku itu terlihat pada tokoh si aku yang suka menyendiri dan menempatkan diri pada sudut ruang rumah. Lalu, tindakan kesedihan atau ketidaktegaan yang diungkapkan para tetangga atau tamu terhadap si aku merupakan petanda. Perilaku dan tindakan itu membentuk suatu simbol ditunjukan dengan senyuman. Senyuman merupakan konvensi yang ditangkap dari penanda dan petanda dalam diri si aku. Senyuman itu merupakan simbol dari kehadiran si aku sebagai simbol universal. Simbol universal itu didasarkan pada hal-hal dibentuk dan dikembangkan dari perilaku yang dialami tokoh. $\mathrm{Hal}$ itu terlihat dalam kutipan berikut.

A papun komentar mereka, saya akan tersenyum. Ya, karena saya tidak bisa bicara. Sudah lama saya berlatih, setiap ingin bicara atau berteriak saya mengalihkannya dengan tersenyum. Karena suara yang keluar dari mulut saya hanya melenguh. Dan saya tidak menyukai suara lenguhan.

Senyuman sebagai konvensi yang ditangkap dan dimaknai menjadi identitas diri secara universal. Budaya masyarakat yang ramah dan mudah bergaul menjadi identitas diri bangsa. Begitu pula sikap ramah dan suka bertegur sapa juga saling tolong telah menjadikan jati diri begitu tampak dalam kehidupan masyarakat. Masyarakat ramah dan sopan telah menjadi simbol jadi diri. Tidaklah berlebihan, bila setiap bertatap muka, kita akan bertutur sapa dan berupaya saling mengenal.

Makna senyuman yang menunjukan simbol kultur, yaitu kebutuhan tokoh dalam cerita untuk berinteraksi dan bersosialisasi sebagai penanda. Petanda simbol kultur itu ditunjukkan pada kebutuhan untuk bertegur sapa. Tokoh dalam cerpen berperilaku sal ing bertegur saat mereka bertemu. Simbol senyuman yang diungkapkan oleh tokoh si aku dapat dimaknai sebagai bentuk komunikasi dan interaksi serta reaksi terhadap sekelilingnya. $\mathrm{Hal}$ itu juga dimaknai sebagai kesopanan dan keramahan. Hal itu terlihat dalam kutipan berikut.

\footnotetext{
"O h, itu A nelis cucu Ibu itu, ya?" tanya tamu sambil tersenyum kepada saya. $\mathrm{N}$ enek selalu mengangguk menjawab pertanyaan seperti itu. Sang tamu kemudian menghampiri saya. "Oh, cantik sekali. Rambutnya begitu indah, matanya begitu cerlang."
}

Kutipan di atas menjelaskan bahwa kultur masyarakat yang suka menyapa terlihat pada tokoh tamu. Tamu menyapa Anelis yang duduk di pojok rumah. Selain itu, juga terlihat ada upaya tamu untuk mengungkapkan perasaan, kendati tidak sesuai dengan realita yang ada, memuji kecantikan dan indahnya rambut Anelis serta kecerlangan matanya. Sikap itu merupakan bentuk tata kesopanan yang telah mengakar dalam masyarakat. Sikap menghargai orang lain begitu kuat dalam masyarakat. Juga ada upaya untuk menjaga perasaan tuan rumah. Sikap tamu akan berusaha memuji, walaupun sesungguhnya bertolak belakang. Hal ini menjadi identitas diri dan mengendap dalam simbol senyuman sebab senyuman sebagai bagian dari ekpresi keramahan dan keakraban.

Lalu, makna senyuman dalam tataran individual yang ditunjukkan oleh tokoh si aku adalah berdiam diri dan senyum. Sikap berdiam diri sebagai penanda dalam merespon hal yang ditujukan padanya. Reaksi senyum yang mengembang dan tidak mengeluarkan kata- 
kata sebagai petanda. A pa pun yang diungkapkan oleh tamu atau tetangga dirinya akan melakukan hal tersebut. Tindakan dan sikap itu menjadi simbol individual yang merujuk pada ciri atau identitas pribadi seseorang. Gadis senyuman melekat pada diri si aku. Karena senyum sebagai alat untuk merespon, si aku melakukannya tanpa reaksi yang lain. Hanya dengan senyuman saja dirinya merasakan komunikasinya akan tersampaikan dan dipahami. Hal itu terlihat dalam kutipan berikut

Sebulan kemudian Inalis berselisih de ngan tetangganya. Setahun kemudian Inalis dijauhi semua tetangganya. Hidup Inalis seperti terasing. Hidup menyendiri di tengah keramaian. Bertemu dengan saya para tetangga itu menyapa dan tersenyum. Tapi begitu melihat Inalis, mereka seperti tidak saling mengenal.

Kutipan di atas menjelaskan bahwa sikap Inalis yang tidak mampu menjaga bibirnya. Kehidupan dirinya menjadi hancur. Inalis berselisih dengan tetangganya.Setahun kemudian Inalis dijauhi oleh semua tetangga hingga dia hidup sendiri dan terasing. Inalis sebagai simbol individual yang tidak pernah mampu menjaga bibirnya. Tidak pernah menjaga ucapan dan perkataannya. Jangankan untuk berkata baik, senyum pun tidak mampu dilakukan. $\mathrm{Hal}$ ini telah menjadikan dirinya terbuang dan terasingkan oleh lingkungaan. Inalis menjadi simbol kontra dari makna simbol senyuman. Untuk itu, Inalis pernah berharap untuk bisa menjadi Anelis. Anelis sebagai perempuan sunyi yang penuh dengan senyuman.

\section{PENUTUP}

\section{Simpulan}

Dari analisismakna simbol senyuman dalam cerpen Perempuan Sunyi dan Saudaranya karya Yus R. Ismail didapat simbol universal, yaitu pertama, simbol yang berkaitan dengan arketipus. Simbol ini merupakan pola yang dasar yang terlihat dal am kelompok atau masyarakat.
Lalu, simbolini dijadikan sebuah simbol indentitas diri secara umum; kedua, simbol kultural, yaitu simbol yang melatarbelakangi suatu kebudayaan tertentu. Simbol yang hadir dalam masyarakat tertentu.Hal ini telah menjadi kebiasaan atau budaya masyarakat. Juga telah melekat sebagai jati diri masyarakat; dan ketiga, simbol individual, yaitu simbol yang dipakai ke dalam studi bahasa masyarakat dan lingkungan. Simbol ini merupakan bentuk identiatas diri yang tercermin dalam sikap dan perilaku individu yang bersifat perseorangan. Simbol ini mempengaruhi simbol universal dan simbol kultural. Sebaliknya, simbol individual ini juga dipengaruhi oleh simbol universal dan simbol kultural. Artinya ketiga simbol itu akan saling mempengaruhi untuk membentuk se buah indetitas diri tertentu.

Makna simbol senyuman dalam cerpen Perempuan Sunyi dan Saudaranya Yus R. Ismail ini dapat memberikan pengetahuan dan pemahaman terhadap kehidupan. Bila pengetahuan dan pemahaman terhadap kehidupan meningkat, gejala kehidupan dapat disikapi dengan positif. Artinya simbol-simbol dalamkehidupan dapat dimaknai dan diartikan secara tepat, maka banyak hal yang dapat diambil sebagai nilai kehidupan. Begitu pula sebaliknya bila tidak cermat dan teliti dalam memaknai simbol kehidupan, kita akan tidak mendapatkan kesempurnaan dalam kehidupan.

\section{Saran}

Penelitian terhadap cerpen Perempuan Sunyi dan Saudaranya karya Yus R. Ismail dapat diteliti dari segi struktur dengan pendekatan struktural karena memiliki kekhasan. Penelitian struktur untuk menangkap makna komponen pembentuk karya. Selain itu, dalam cerpen Perempuan Sunyi dan Saudaranya karya Yus R. Ismail ini dapat dilihat nilai-nilai sosial budayanya sehingga pendekatan sosiologi sastra pun dapat dilakukan. Penelitian dengan pendekatan ini akan didapat gambaran kehidupan sosial budaya pengarang dan lingkungan pengarang serta kehidupan dalam 
karya. Tentu, juga cerpen Perempuan Sunyi dan Saudaranya ini dapat diteliti dengan menggunakan pendekatan psikoanalisis. Dengan pendekatan ini akan didapat sikap dan kepribadian melalui perilaku dan peristiwa yang dialami tokoh si aku, Anelis dan Inalis.

\section{DAFTAR PUSTAKA}

A ini. "A nalisis Semiotik terhadap N ovel Laskar pelangi Karya Andrea Hirata Sebagai Alternatif Bahan Pengajaran Sastra di SMA". Jurnal IImiah Nosi Volume 1, Nomor 2, A gustus 2013.

Barnet, Berman, Bruto. 1992. An Introduction to Literature. Di Indonesiakan oleh. Dick H artoko. Jakarta: PT.Gramedia.

Budiman, Kris. 2011. Semiotika Visual. Yogyakarta: Buku Baik.

Chaer, A bdul. 2002. Pengantar Semantik Bahasa Indonesia. Jakarta: PT. Rineka Cipta.

Endraswara, Suwardi. 2008. M etodologi Penelitian Sastra: Epistemologi, M odel, Teori, dan A plikasi. Yogyakarta: Media Presindo. Penelitian Sastra. Jakarta: CAPS.

Ismail, Yus R. “Cerpen Perempuan Sunyi dan Saudaranya" dimuat M edia Indonesia, 10 September 2017.

Luxemburg, dkk. 1989. Tentang Sastra. Jakarta: Intermasa.

Lyons, J. 1984. Semantics 1. Cambridge: Cambridge University Press.

Pickering, James H. and Jeffrey D. Hoeper. 1981. Concise Companion to Literature. N ew York : McMillan Publishing.

Moleong. L.J. 2005. M etode Penelitian Kualitatif. Bandung: Remaja Karya.

Santoso, Puji. 1993. Ancangan Semiotika dan Pengkajian Susastra.Bandung:A ngkasa

Sumarto, A. Sardju. 1984. Pengantar Linguistik U mum. Bandung: Institut Tekhnik Bandung.
Supratno, Haris. 2010. Sosiologi Seni: Wayang Sasak Lakon Dewi Rengganis dalam Konteks Perubahan M asyarakat di Lombok. Surabaya: Unesa Univesity Press.

Rifai, Whafik Muhammad. 2011. Simbol dan M akna N ovel Candhikala Kapuranta karya Sugiarta Sriwibawa. Fakultas Bahasa dan Seni, Universitas Negeri Semarang.

Rosyada, HardiniVani. 2014. Simbol "Gila" dalam Cerpen Catatan Harian Orang Gila karya Lu X un. FIB UI: Program Studi Cina.

Sobur, Alex. 2009. Semiotika Komunikasi. Bandung: Remaja Rosdakarya.

Teeuw, A. 1994. Sastra dan IImu Sastra: Pengantar Teori Sastra. Jakarta: Pustaka Jaya. 